\title{
ХIII ВСЕУКРАЇНСЬКА НАУКОВО-ПРАКТИЧНА КОНФЕРЕНЦІЯ «ПІВДЕНЬ УКРАЇНИ В УМОВАХ ГЛОБАЛЬНИХ СОЦІОКУЛЬТУРНИХ ТРАНСФОРМАЦІЙ: ПИТАННЯ КУЛЬТУРНОЇ, ЕТНОРЕЛІГІЙНОЇ ТА НАЦІОНАЛЬНО-ГРОМАДЯНСЬКОЇ ІДЕНТИЧНОСТІ»
}

3-4 жовтня 2019 року в приміщенні Національного університету «Запорізька політехніка» кафедра українознавства та загальної мовної підготовки при сприянні Міністерства освіти і науки України, Інституту політичних і етнонаціональних досліджень ім. І.Ф. Кураса НАН України, Запорізької обласної державної адміністрації, Департаменту культури, туризму, національностей та релігій Запорізької обласної державної адміністрації, Національного університету «Запорізька політехніка» та Запорізького обласного краєзнавчого музею провела традиційну XIII Всеукраїнську науково-практичну конференцію «Південь України в умовах глобальних соціокультурних трансформацій: питання культурної, етнорелігійної, етнічної та національно-громадянської ідентичності». В конференції, окрім запорізьких науковців, взяли участь представники наукових осередків Київщини, Одещини та Херсонщини. Загалом на конференцію було подано більше вісімдесяти наукових статей і матеріалів.

3 привітальним словом до учасників конференції від імені їі організаторів звернулись: ректор Національного університету «Запорізька політехніка», доктор технічних наук, професор С.Б. Бєліков; завідувач відділу національних меншин Інституту політичних і етнонаціональних досліджень ім. І.Ф. Кураса НАНУ, доктор політичних наук, професор В.0.Котигоренко.

Цього разу інтегральною темою дискусії стали глобальні, загальноукраїнські та регіональні виклики етнокультурній, етнорелігійній та етнополітичній ситуації у країні у зв'язку з впливом цих викликів на динаміку феномена національно-громадянської ідентичності в українському соціумі.

Найбільш потужною делегацією за 25 років проведення конференції у складі 6 осіб був представлений Інститут політичних і етнонаціональних досліджень ім. І.Ф. Кураса Національної академії наук України.

На пленарному засіданні зі своїми доробками виступили: завідувач відділу національних меншин Інституту політичних і етнонаціональних досліджень ім. І.Ф. Кураса НАНУ, доктор політичних наук, професор В.О. Котигоренко «Націоналізм у глобалізованому світі: український контекст», провідний науковий співробітник Інституту політичних і етнонаціональних досліджень ім. I.Ф. Кураса НАНУ, доктор історичних наук, професор Ю.0. Ніколаєць «Історична політика в Україні 2014-2018 рр.»; провідний науковий співробітник відділу національних меншин Інституту політичних і етнонаціональних досліджень ім. І.Ф. Кураса НАНУ, доктор політичних наук С.Ю. Римаренко «Релігійні особливості соціокультурного простору України»; молодший науковий співробітник відділу національних меншин Інституту політичних і етнонаціональних досліджень ім. I.Ф. Кураса НАНУ, кандидат історичних наук В.В. Новодворський «Кримськотатарське національне питання у повоєнні роки: науковий дискурс; молодший науковий співробітник відділу етнополітологї̈ Інституту політичних і етнонаціональних досліджень ім. І.Ф. Кураса НАН України, кандидат історичних наук С.В. Набок «Символічні маркери Другої світової війни в сучасному політичному просторі»; провідний науковий співробітник відділу теорії та історії політичної науки Інституту політичних і етнонаціальних досліджень ім. І.Ф. Кураса НАНУ, кандидат історичних наук А.Ю. Подольський «Формування культури пам'яті про жертви голокосту в Україні: суспільно-політичні виклики і перспективи» та ін.

У другій половині першого дня, після годинної перерви та неформального спілкування науковців, учасники конференції взяли участь у засіданні 5 секцій: «Громадянське суспільство в етнополітичних процесах в Україні», «Етнічна структура населення регіону: історія і культура», «Правові аспекти державної етнополітики: еволюція та сучасність», Інтелект та духовність: національний вимір» та «Етнонаціональний аспект державної мовної й освітньої політики».

4 жовтня був проведений круглий стіл: «Врахування етнокультурних особливостей Півдня України при розробці та проведенні державної етнополітики», найактивнішу участь в роботі якого прийняли: голова Запорізького товариства та- 
тарської культури «Алтин - Ай» Р. С. Ахмерова, голова Запорізького обласного литовського товариства Р. П. Балтушіте-Фалькевич, голова обласного товариства польської культури ім. А. Міцкевича 0. Ю. Павлюк, завідувачка лабораторією технічного прогресу Національного університету «Запорізька політехніка» Н. В. Деркач та інші.

На підсумковому пленарному засіданні керівники секцій та круглого столу відзначили високий рівень наукової новизни і практичного значення результатів виступів вчених і представників національних громад. Учасники конференції зазначили, що продовжують зберігатись творчі зв'язки між науковцями різних поколінь, наукових шкіл $\mathrm{i}$ регіонів України. Крім того, учасники підсумкового пленарного засідання виразили надію, що виказані на конференції результати проведених науковцями досліджень знайдуть втілення у практичній діяльності як учених, так і національно-культурних товариств. Також учасники конференції відзначили вкрай важливу роль таких традиційних науково-практичних конференцій в сучасному складному суспільно-політичному житті як Південної України, так і держави в цілому. Подальше проведення означених науково-прак- тичних зібрань на думку науковців $є$ доцільним.

На підсумковому пленарному засіданні учасники схвалили резолюцію, в якій означено низку етнополітичних проблем, розв'язання яких потребує ініціативних дій з боку державних органів та інституцій місцевого самоврядування і громадянського суспільства, сформульовано пропозиції щодо змісту таких дій, окреслено питання, пошук відповідей на які потребує поглиблених наукових досліджень з наступним обговоренням їх результатів на наукових зібраннях за участю представників влади і громадянського суспільства.

Організатори конференції передбачили для $і 17$ учасників і культурно-розважальну програму, що складалася з відвідання Музею історії технічного прогресу Національного університету «Запорізька політехніка», Запорізького обласного краєзнавчого музею та Музею техніки ім. Богуслаєва.

Група науковців звернулась до організаторів конференції з пропозицією залучати до даних наукових зібрань дослідників Південної України з інших країн і таким чином, відновити міжнародний статус цих конференцій.

М. В. ДєӘков 